\title{
Prinsip Kerja dan Komponen - Komponen Pembangkit Listrik Tenaga Air (PLTA) Wahyu Hidayat \\ wahyu.hidayat@lecture.unjani.ac.id
}

\subsection{Gambaran Umum PLTA dan Instalasi Pembangkit Tenaga Air}

PLTA adalah suatu pembangkit listrik dengan media kerja air. Secara umum, PLTA adalah mesin konversi energi yang terdiri dari dam (bendungan), reservoir, penstock (pipa pesat), turbin, draft tube, power house dan electricity terminal

Dalam suatu sistem PLTA (Pembangkit Listrik Tenaga Air), turbin merupakan suatu peralatan utama selain generator. Sistem kerjanya adalah dengan memanfaatkan arus aliran air dari sungai yang kemudian di tampung pada sebuah dam (bendungan) yang kemudian dialirkan pada suatu rangkaian pipa agar energi potensial air dapat diubah menjadi energi kinetik, sehingga pada akhirnya diubah kembali menjadi energi mekanis untuk menggerakkan atau memutarkan turbin hal tersebut menyebabkan generator yang seporos dengan turbin dapat berputar, maka dengan proses yang terjadi tersebut induksi elektromagnetik yang menghasilkan energi listrik.

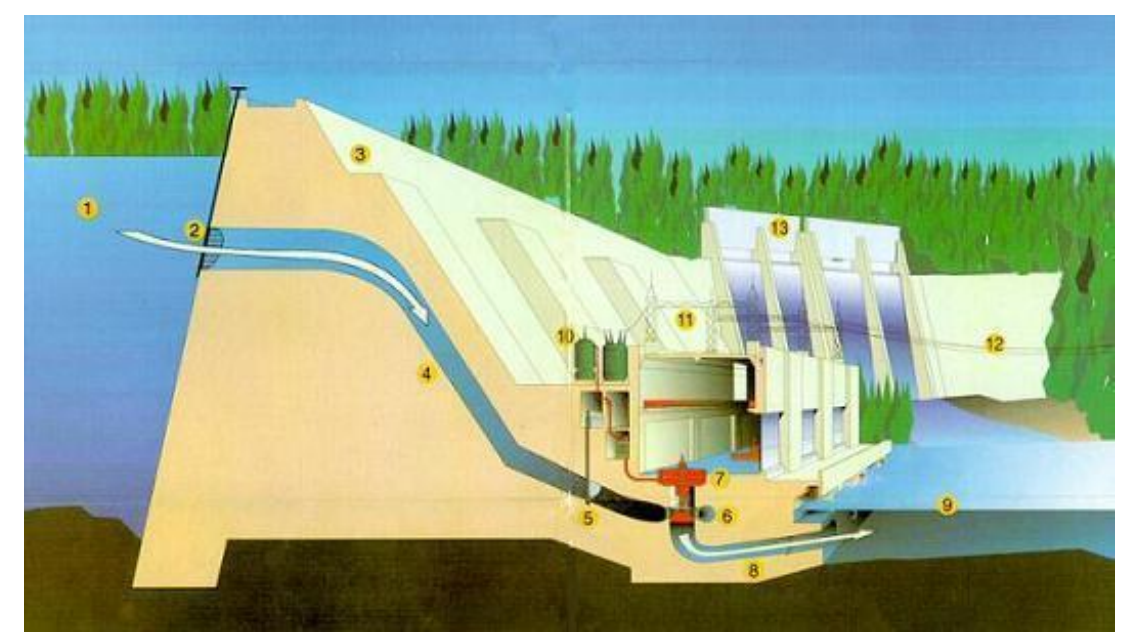

Gambar 1.1 Gambaran Instalasi PLTA 


\subsubsection{Prinsip Kerja PLTA}

Sebelumnya kita harus tahu apa itu PLTA, Pembangkit Listrik Tenaga Air (PLTA) bekerja dengan cara merubah energi potensial dari bendungan (dam) atau air terjun menjadi energi mekanik dengan bantuan turbin air dan dari energi mekanik menjadi energi listrik dengan bantuan generator.

Kapasitas daya yang dihasilkan PLTA diseluruh dunia ada sekitar 675.000 MW atau setara dengan 3,6 milyar barrel minyak atau sama dengan $24 \%$ kebutuhan listrik dunia yang digunakan oleh lebih 1 milyar orang. Komponen - kompnen dasar PLTA berupa bendungan (dam), turbin, generator dan transmisi.PLTA merubah energi yang disebabkan gaya jatuh air untuk menghasilkan energi listrik. Turbin mengkonversi tenaga gerak jatuh air ke dalam daya mekanik. Kemudian generator mengkonversikan daya mekanik tersebut dari turbin ke dalam tenaga elektrik. Jenis PLTA bermacammacam, mulai yang berbentuk "mikro-hidro" dengan kemampuan mensupalai untuk beberapa rumah saja sampai berbentuk raksasa seperti Bendungan Karangkates yang menyediakan listrik untuk berjuta - juta orang-orang. Photo dibawah ini menunjukkan PLTA di Sungai Wisconsin, merupakan jenis PLTA menengah yang mampu mensuplai listrik untuk 8.000 orang.

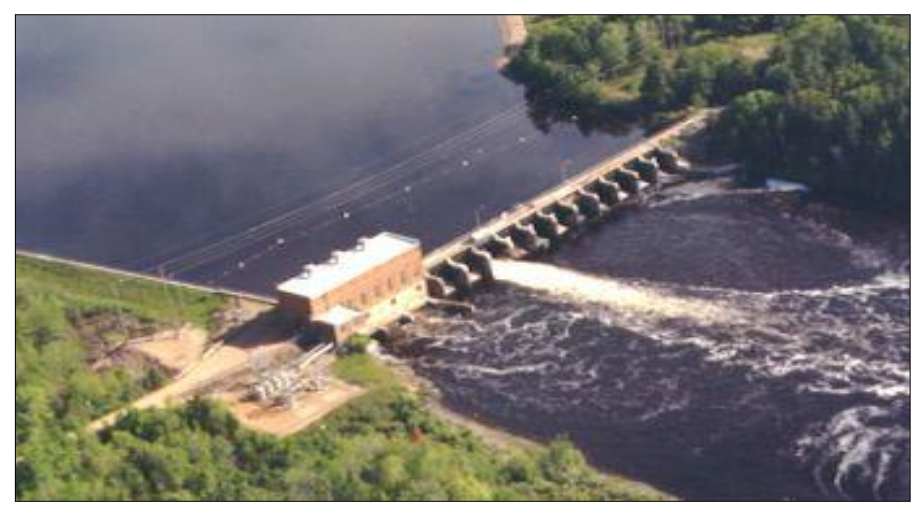

Gambar 1.2 Aliran pada PLTA 


\subsubsection{Komponen PLTA dan Cara Kerjanya}

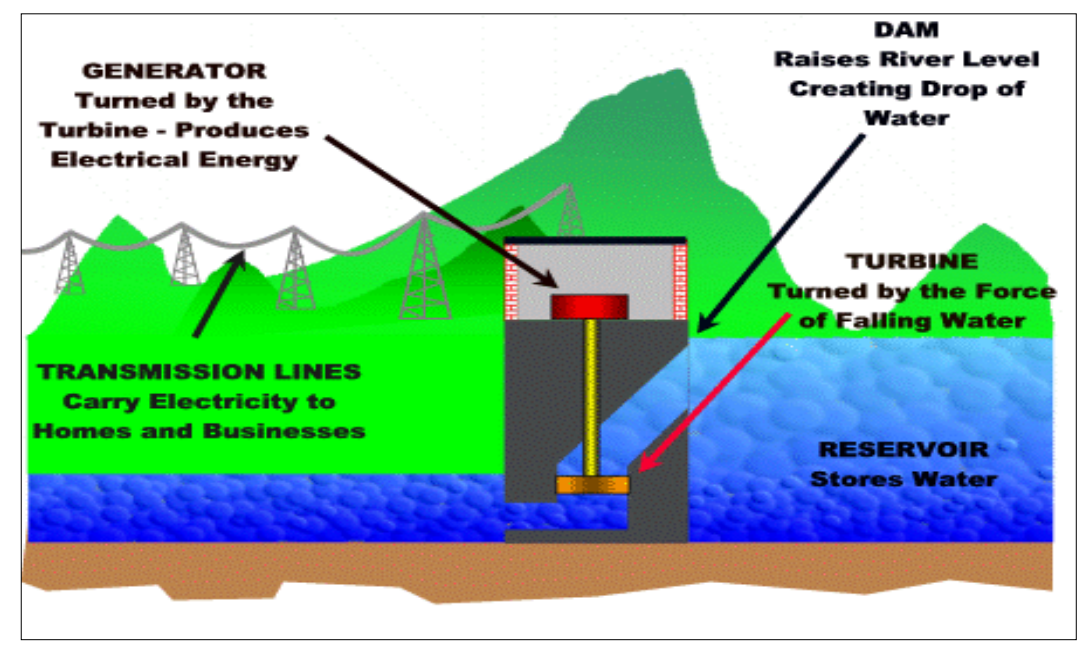

Gambar 1.3 Instalasi PLTA

\section{Bendungan}

Berfungsi menaikkan permukaan air sungai untuk menciptakan tinggi jatuh air. Selain menyimpan air, bendungan juga dibangun dengan tujuan untuk menyimpan energi.

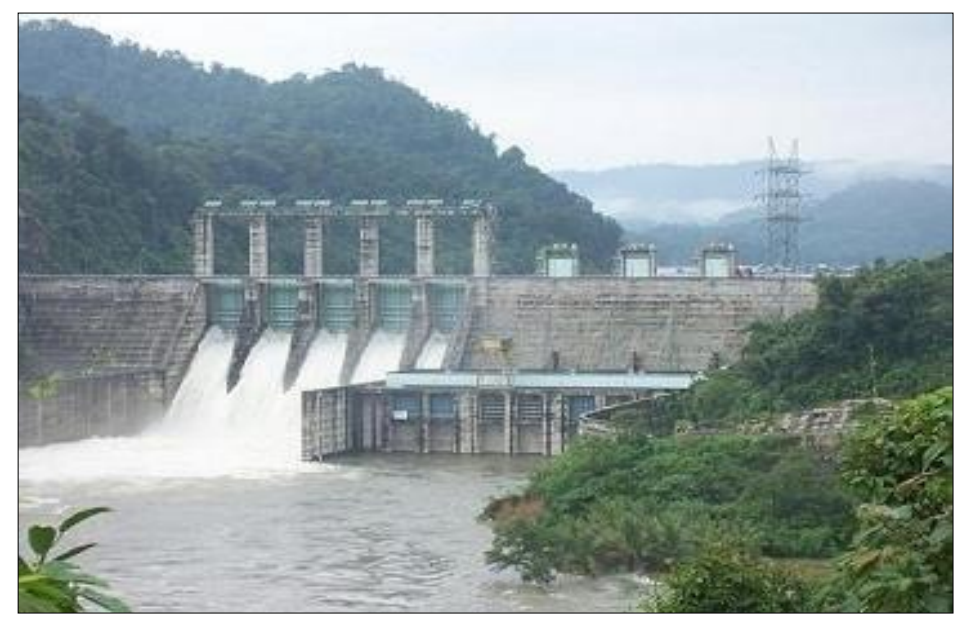

Gambar 1.4 Bendungan 


\section{Turbin}

Gaya jatuh air yang mendorong sudu turbin menyebabkan turbin berputar. Turbin air kebanyakan seperti kincir angin, dengan menggantikan fungsi dorong angin untuk memutar baling - baling digantikan air untuk memutar turbin. Selanjutnya turbin merubah energi kenetik yang disebabkan gaya jatuh air menjadi energi mekanik.

\section{Generator}

Generator dihubungkan dengan turbin melalui gigi - gigi putar sehingga ketika baling - baling turbin berputar maka generator juga ikut berputar. Generator selanjutnya merubah energi mekanik dari turbin menjadi energi elektrik. Generator di PLTA bekerja seperti halnya generator pembangkit listrik lainnya.
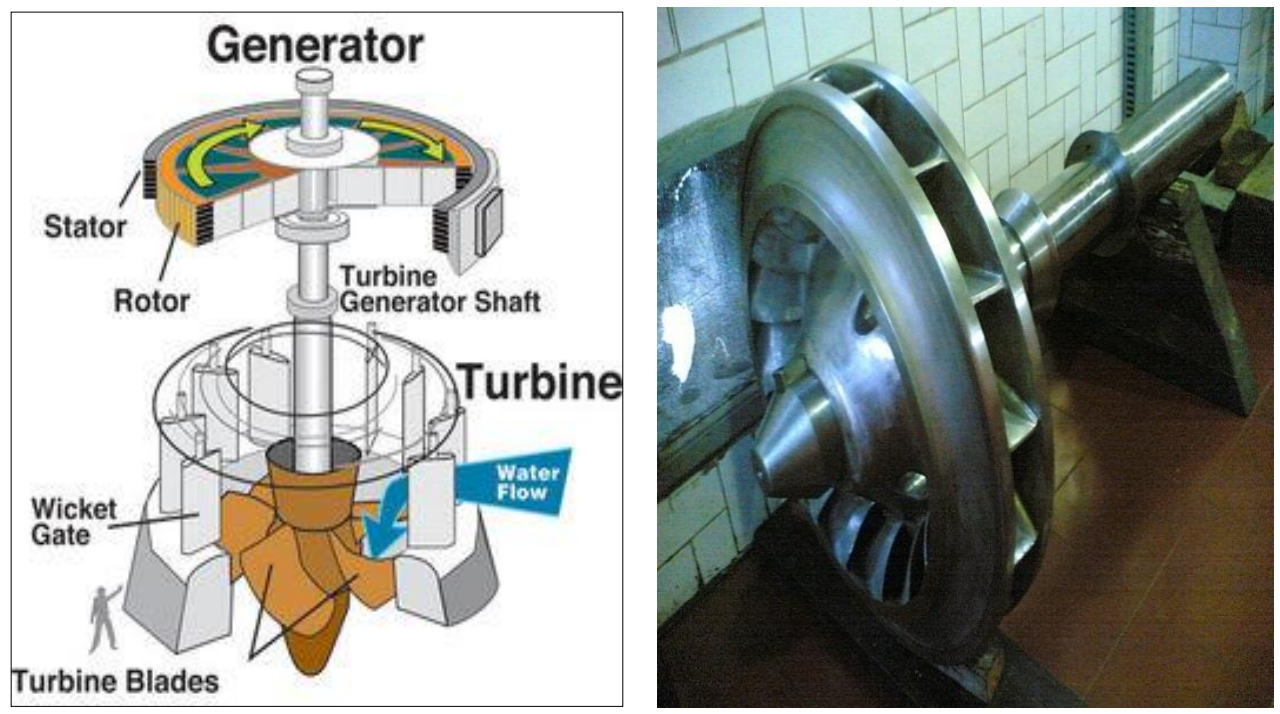

Gmanbar 1.5 Turbin \& Generator 


\section{Jalur Transmisi}

Berfungsi menyalurkan energi listrik dari PLTA menuju rumah - rumah dan pusat industri.

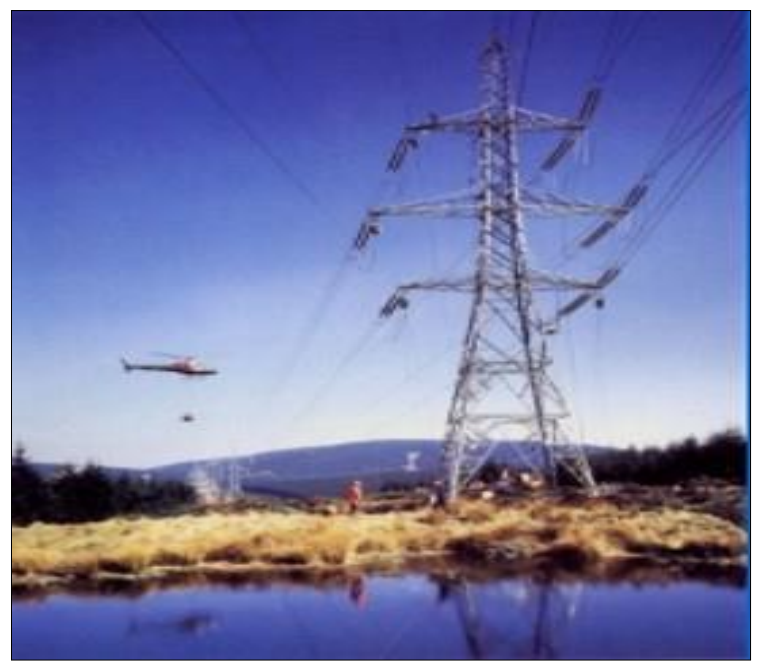

Gambar 2.6 Jalur Transmisi

\subsection{Sekilas Unit Bisnis Pembangkit Saguling}

UBP Saguling adalah Unit Bisnis Pembangkitan yang menggunakan tenaga air sebagai penggerak utama (prime mover). Pengembangan Pusat Listrik Tenaga Air (PLTA) merupakan perwujudan upaya pemerintah untuk melakukan diversifikasi tenaga listrik dan konservasi minyak bumi. UBP Saguling mengelola 29 mesin pembangkit yang tersebar di Jawa Barat dengan Total Kapasitas terpasang 797,36 MW. Beberapa kelebihan PLTA Saguling adalah : Waktu pengoperasiannya relatif lebih cepat (15 menit), Sistem operasinya mudah mengikuti beban dan frekuensi yang diinginkan oleh sistem penyaluran, Biaya produksinya relative lebih murah, karena menggunakan air dan tidak perlu membeli, putaran turbin relatif rendah dan tidak berhubungan dengan panas, sehingga tingkat kerusakan peralatan menjadi lebih kecil, PLTA adalah jenis pembangkit yang ramah lingkungan, tanpa melalui proses pembakaran sehingga tidak menghasilkan limbah bekas pembakaran, PLTA yang dilengkapi dengan waduk dapat difungsikan secara multiguna. UBP Saguling 
membawahi 8 Sub -Unit Pembangkitan, yaitu : PLTA Saguling, PLTA Plengan, PLTA Lamajan, PLTA Cikalong, PLTA Bengkok dan Dago, PLTA Ubrug, PLTA Kracak dan PLTA Parakankondang Satu diantara fungsi UBP Saguling, dalam sistem kelistrikan se Jawa-Bali,mselain untuk memikul beban puncak, juga berfungsi sebagai pengatur frekuensi sistem. Hal ini dimungkinkan dengan diterapkannya peralatan LFC (Load Frequency Control).

Tabel. 1 Mesin - Mesin Yang Dibangkitkan di Bawah UBP Saguling

\begin{tabular}{|l|c|c|c|}
\hline \multicolumn{1}{|c|}{ Nama Mesin } & JumlahMesin & Kapasitas Terpasang & Total \\
\hline \hline PLTA Saguling & 4 & $175,18 \mathrm{MW}$ & $700,72 \mathrm{MW}$ \\
\hline PLTA Bengkok & 3 & $1,05 \mathrm{MW}$ & $3,15 \mathrm{MW}$ \\
\hline PLTA Bengkok & 1 & $0,70 \mathrm{MW}$ & $0,70 \mathrm{MW}$ \\
\hline PLTA Plengan & 3 & $1,08 \mathrm{MW}$ & $3,24 \mathrm{MW}$ \\
\hline PLTA Plengan & 1 & $2,02 \mathrm{MW}$ & $2,02 \mathrm{MW}$ \\
\hline PLTA Plengan & 1 & $1,61 \mathrm{MW}$ & $1,61 \mathrm{MW}$ \\
\hline \hline PLTA Lamajan & 3 & $6,52 \mathrm{MW}$ & $19,56 \mathrm{MW}$ \\
\hline \hline PLTA Cikalong & 3 & $6,40 \mathrm{MW}$ & $19,20 \mathrm{MW}$ \\
\hline \hline PLTA Ubrug & 2 & $5,94 \mathrm{MW}$ & $11,88 \mathrm{MW}$ \\
\hline \hline PLTA Ubrug & 1 & $6,48 \mathrm{MW}$ & $6,48 \mathrm{MW}$ \\
\hline \hline PLTA Kracak & 2 & $6,30 \mathrm{MW}$ & $18,90 \mathrm{MW}$ \\
\hline \hline PLTA Parakan Kondang & 2 & $2,46 \mathrm{MW}$ & $4,92 \mathrm{MW}$ \\
\hline \hline PLTA Parakan Kondang & $2,49 \mathrm{MW}$ & & \\
\hline \hline
\end{tabular}

\subsection{Fasilitas Bangunan Di PLTA Bengkok}

Fasilitas bangunan di PLTA Bengkok merupakan suatu fasilitas yang berfungsi untuk menyalurkan air dari sungai atau bendungan menuju ke bangunan power house, 
dimana pada bangunan power house tersebut terdapat turbin yang seporos dengan generator yang bergerak akibat adanya perbedaan permukaan air dari hulu ke hilir karena terdapat energi potensial yang berubah menjadi energi kinetik pada turbin sehingga menghasilkan energi listrik dari generator. Dibawah ini merupakan gambaran situasi fasilitas PLTA Bengkok :

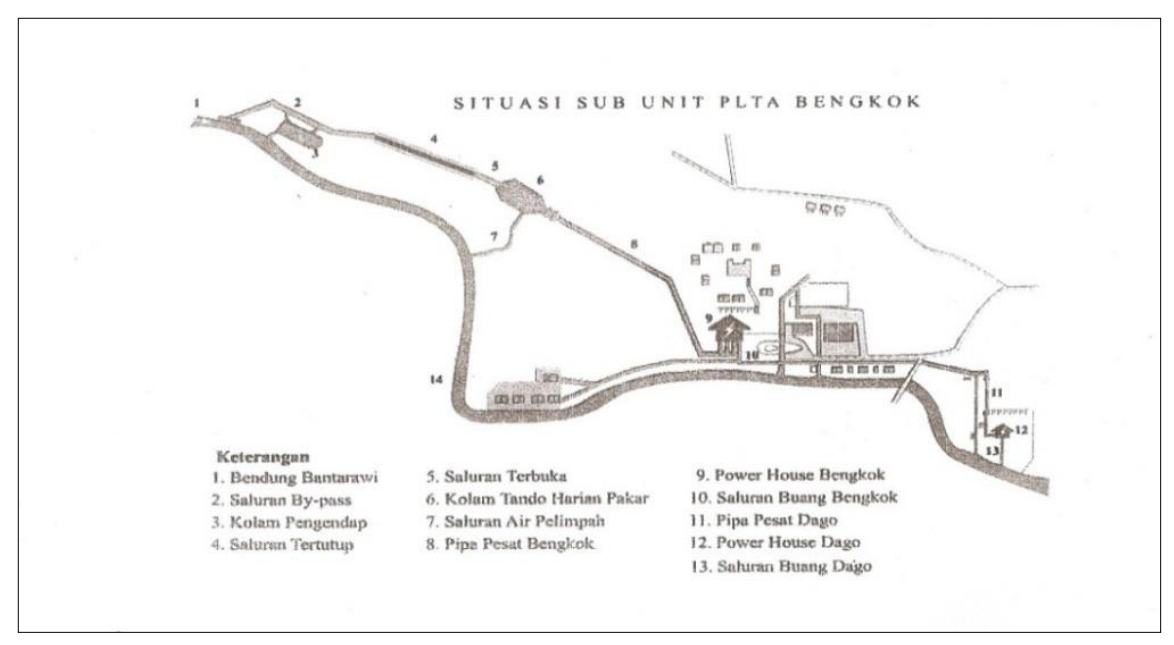

Gambar 1.7 Instalasi Sub Unit PLTA Bengkok

\subsubsection{Bendungan Bantarawi}

Bendungan ini berfungsi untuk membendung air yang berasal dari sungai cikapundung dan mengalihkannya aliran air ke kolam pengendap.

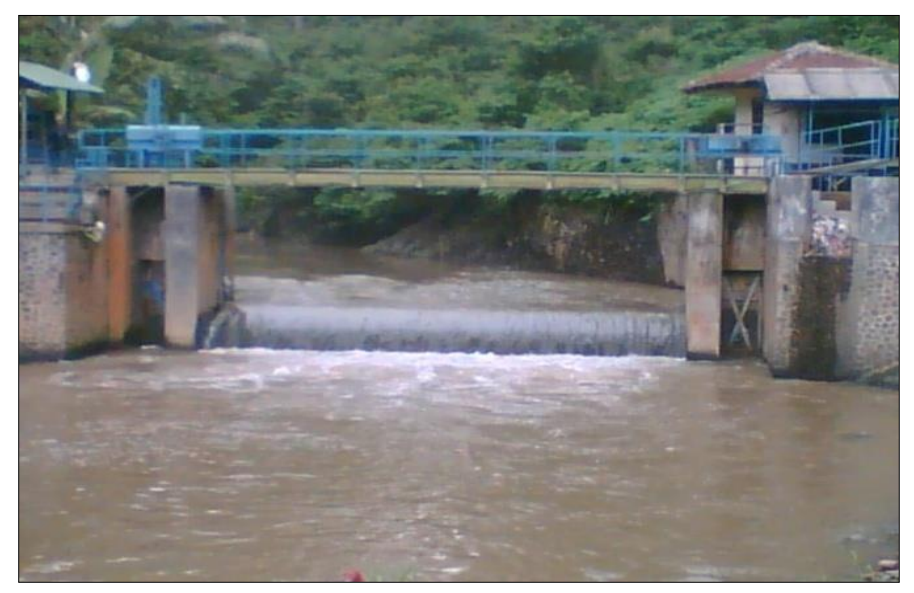

Gambar 1.8 Bendungan Bantarawi 


\subsubsection{Saluran By-Pass}

Saluarn By-Pass ini adalah suatu saluran untuk mengalirkan air yang telah dibendung di bendungan Bantarawi yang selanjutnya dialirkan ke kolam pengendap.

\subsubsection{Kolam Pengendap}

Kolam ini berfungsi agar lumpur-lumpur yang terbawa dengan air tersebut dapat dipisahkan.

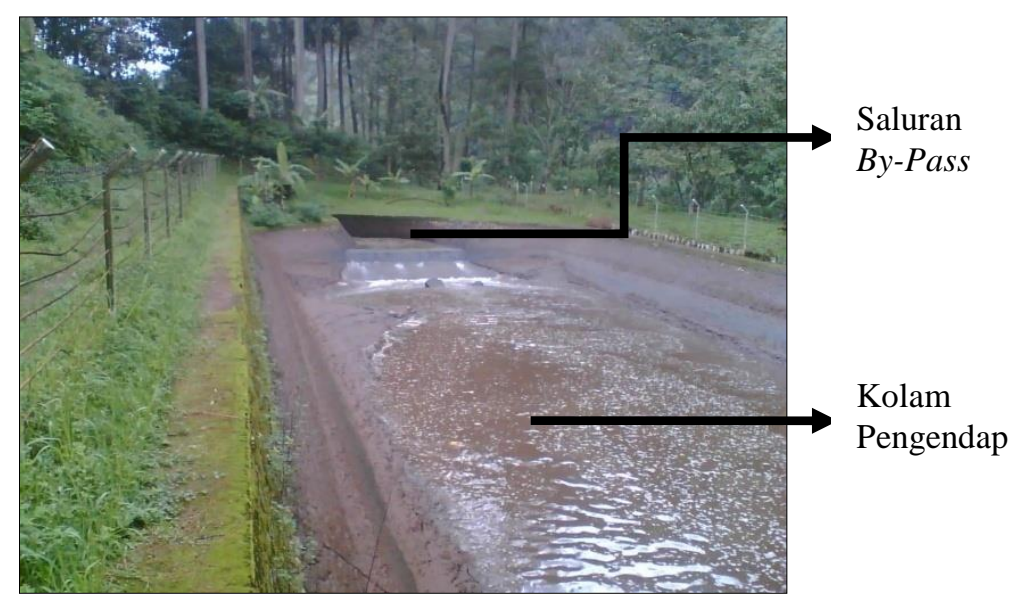

Gambar 2.9 Saluran By-Pass dan Kolam Pengendap

\subsubsection{Saluran Tertutup}

Saluran tertutup merupakan suatu saluran untuk mengalirkan air yang letaknya dibawah permukaan tanah atau saluran ini biasanya juga memakai suatu pipa pada saat profil tanah dalam keadaan yang menurun sehingga air yang mengalir bisa tersalurkan dengan baik. 


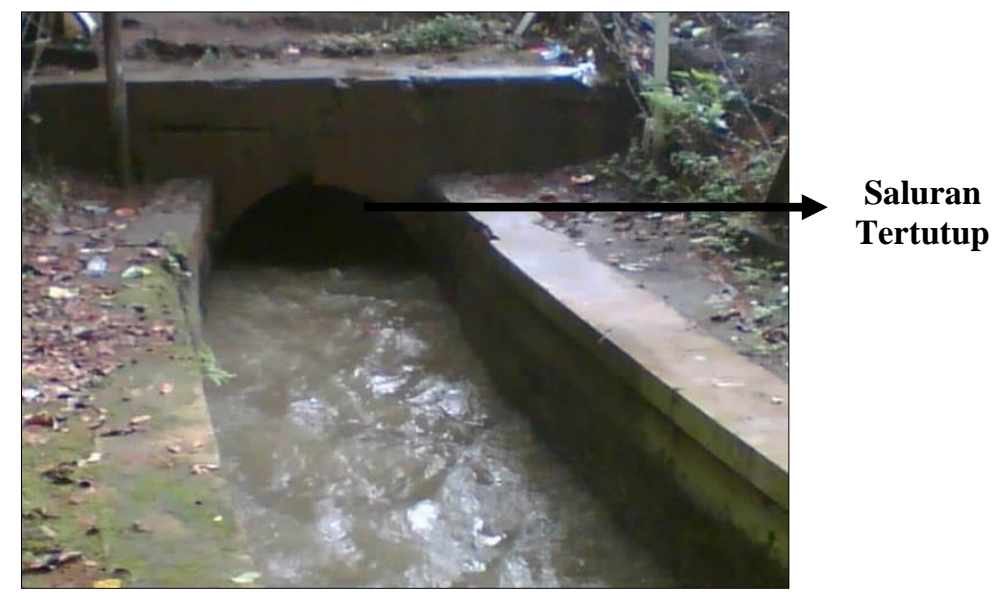

Gambar 1.10 Saluran Tertutup

\subsubsection{Saluran Terbuka}

Saluran terbuka adalah suatu saluran yang fungsinya untuk mengalirkan air yang letaknya dipermukaan tanah.
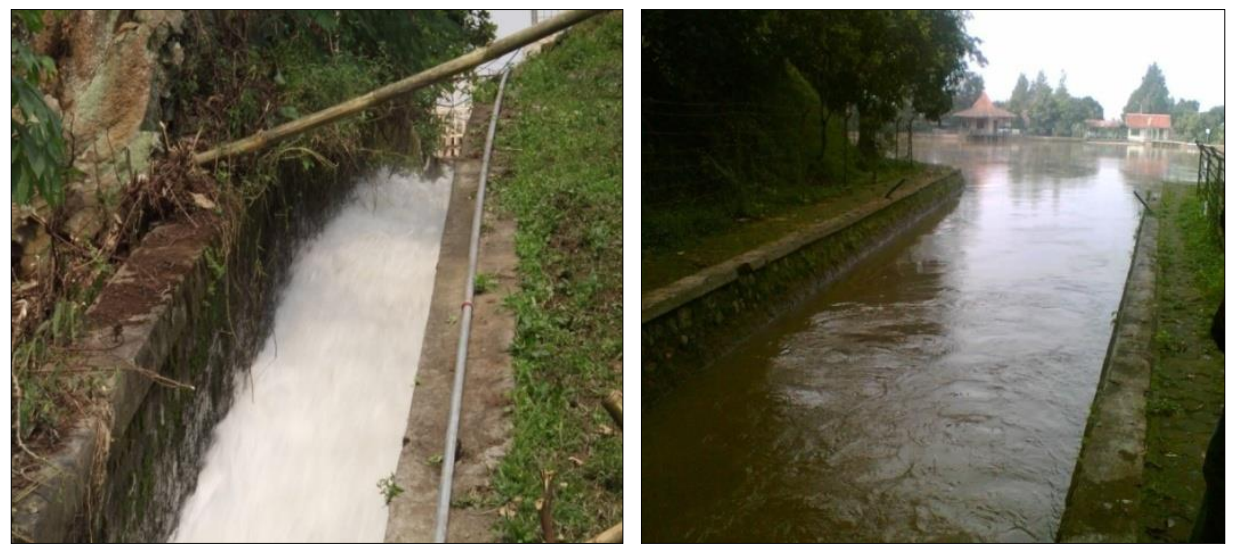

Gambar 1.11 Saluran Terbuka

\subsubsection{Kolam Tando Harian Pakar}

Kolam tando harian pakar adalah suatu kolam penampungan air yang berfungsi untuk menampung air yang berasal dari saluran terbuka yang sekaligus juga berfungsi sebagai kolam untuk mengendapkan lumpur. Kolam tando harian 
pakar ini mempunyai luas \pm 1 hektar dan volume kolam adalah $30.000 \mathrm{~m}^{3}$. Pada kolam tando harian pakar ini juga terdapat saluran air untuk pembuangan, yang fungsinya untuk membuang air ketika air yang masuk ke kolam melebihi kapasitas volume kolam tersebut. Debit air yang masuk adalah sebesar 3.840 $\mathrm{m}^{3} / \mathrm{s}$.

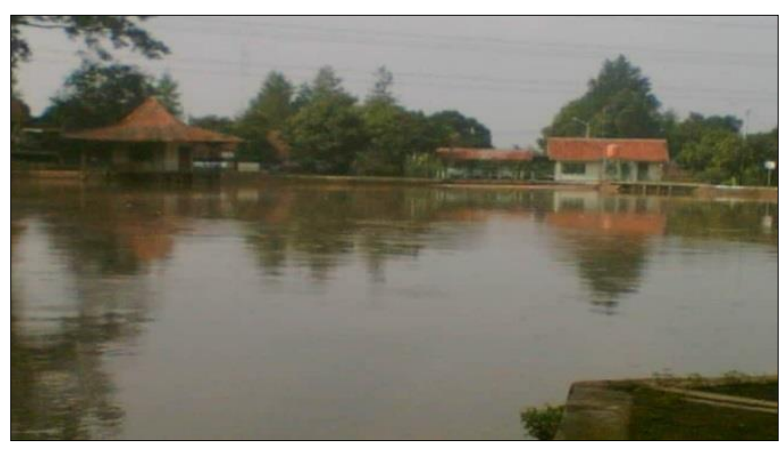

Gambar 1.12 Kolam Tando Harian Pakar

\subsubsection{Saluran Pelimpah}

Saluran pelimpah ini merupakan saluran yang berfungsi untuk membuang air dari kolam tando harian pakar apabila air yang mengalir dari saluran terbuka tersebut telah memenuhi dari kapasitas volume kolam menuju sungai cikapundung.

\subsubsection{Pipa Pesat Bengkok}

Pipa pesat bengkok adalah suatu pipa untuk mengalirkan air dari kolam tando harian pakar menuju turbin sehingga turbin tersebut bisa bekerja akibat adanya perubahan energi, yaitu dari energi potensial air karena terdapat beda ketinggian menjadi suatu energi kinetik pada turbin sehingga turbin tersebut bisa bekerja. 

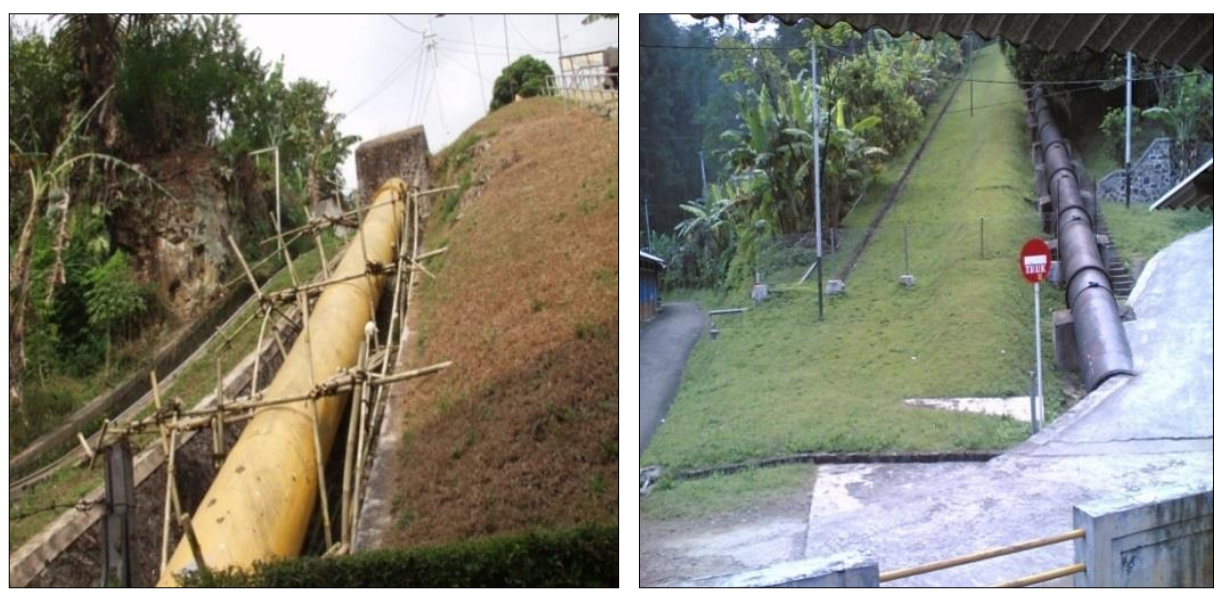

Gambar 1.13 Pipa Pesat Bengkok

\subsubsection{Power House Bengkok}

Power House Bengkok adalah suatu fasilitas bangunan utama yang didalamnya berisi alat-alat atau mesin-mesin untuk menghasilkan tenaga listrik. Salah satu mesin utama dalam power house adalah turbin dan generator, dimana air yang mempunyai energi potensial akibat dari beda ketinggian (head) masuk kedalam rumah keong dari turbin sehingga menghasilkan energi mekanik untuk menggerakkan turbin dan generator.

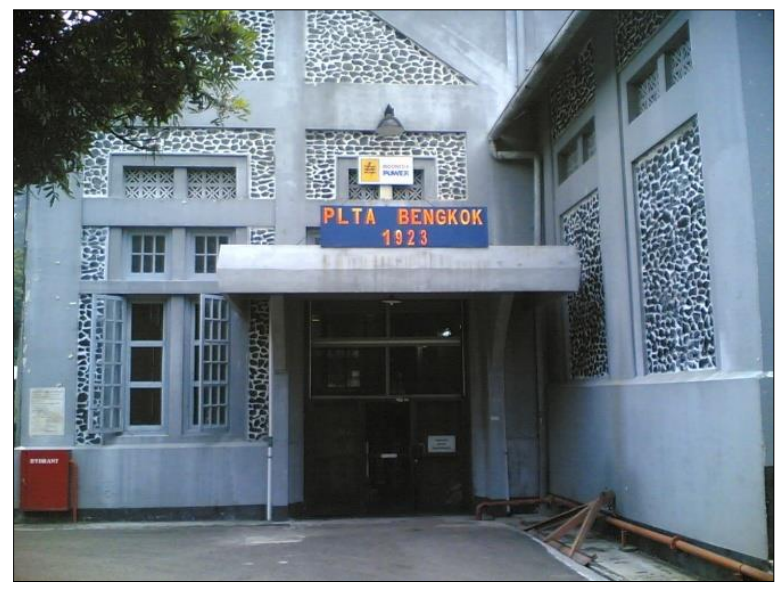

Gambar 2.14 Power House Bengkok 


\subsubsection{Saluran Buang Bengkok}

Saluran buang bengkok merupakan suatu saluran untuk membuang air dari air yang keluar turbin (outlet). Dimana saluran buang ini akan dialirkan kembali ke pipa pesat dago untuk digunakan kembali di PLTA Dago sebagai energi potensial untuk memutarkan turbin menjadi energi mekanik dan generator menghasilkan energi listrik.

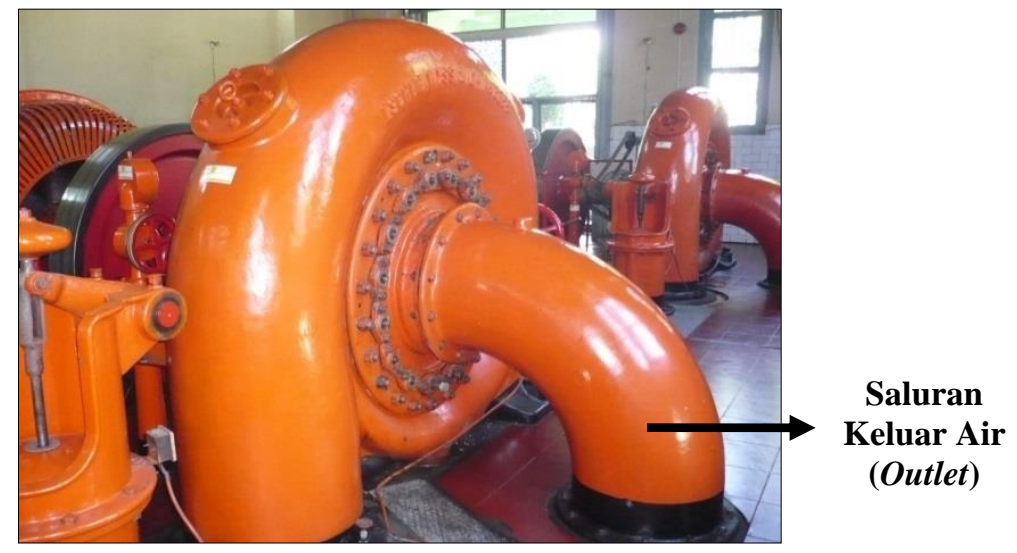

Gambar 1.15 Saluran Outlet

\section{Data Turbin}

Turbin yang digunakan di PLTA Bengkok adalah memakai turbin air dengan jenis turbin francis. Dibawah ini merupakan gambaran dan data teknis turbin air PLTA Bengkok :

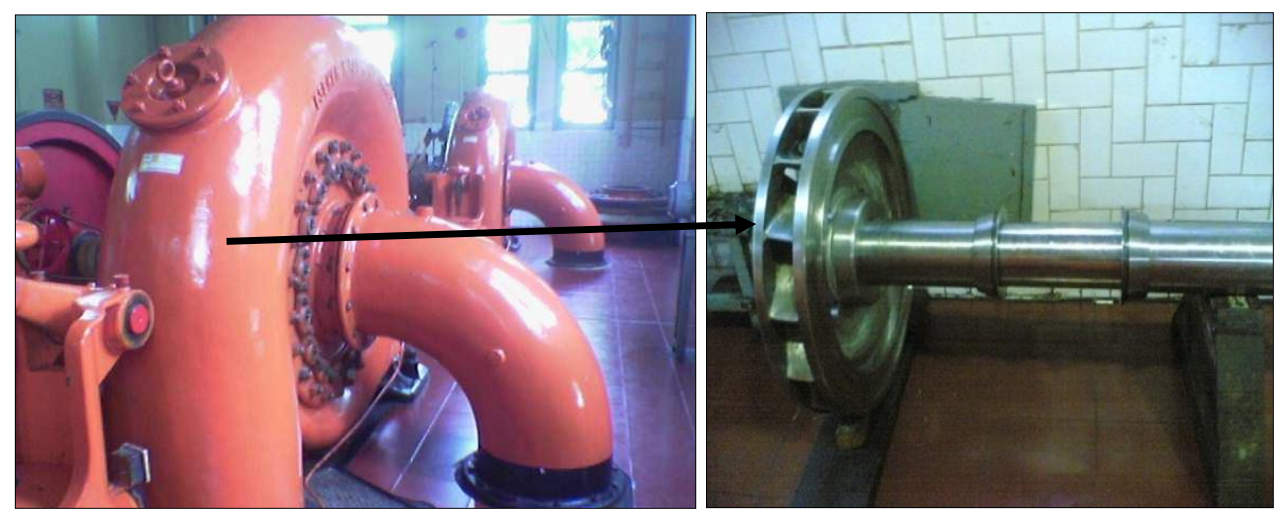

Gambar 2.16 Turbin Air 


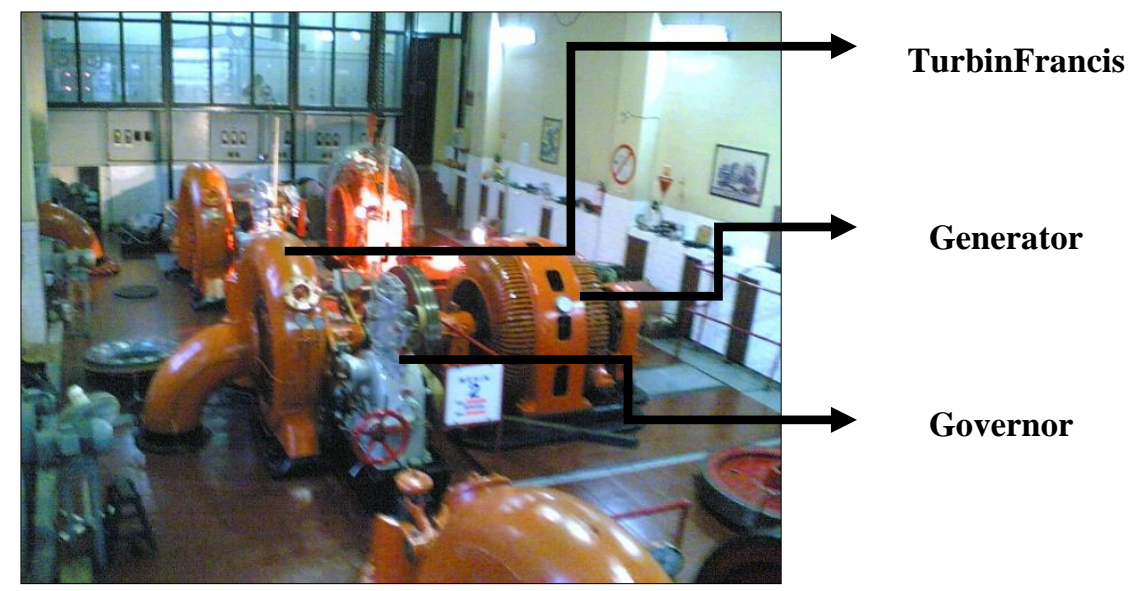

Gambar 1.17 Turbin Francis, Generator dan Governor

Data teknis turbin :

- Jenis turbin

: Turbin air

- Tipe turbin

: Turbin Francis

- Merk

: Escher Wyss

- Daya

: $1500 \mathrm{HP}$

- Daya turbin yang dihasilkan : $1050 \mathrm{KW}$

- Putaran

: $750 \mathrm{rpm}$

- Posisi poros

: Horizontal

- Buatan

: Swiss

\section{Data Governor}

Governor ini digunakan untuk mengatur kecepatan turbin dengan cara mengontrol besarnya pembukaan guide vane pada kondisi beban yang berubahubah. Sehingga dengan menggunkan governor ini putaran turbin dapat relatif konstan. Berikut dibawah ini merupakan data teknis mengenai governor di PLTA Bengkok : 


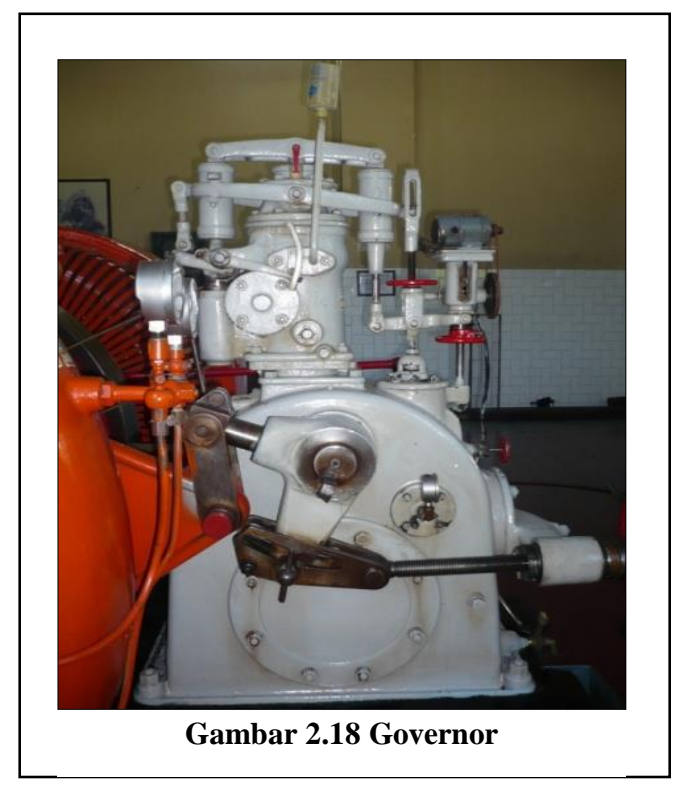

- Merk

: Escher Wyss

- Tipe

$: 37$

- Buatan

: Swiss

\section{Data Generator}

Fungsi dari generator adalah untuk mengubah energi mekanik (dalam bentuk putaran dari turbin) menjadi energi listrik. Berikut ini merupakan data teknis untuk generator : 

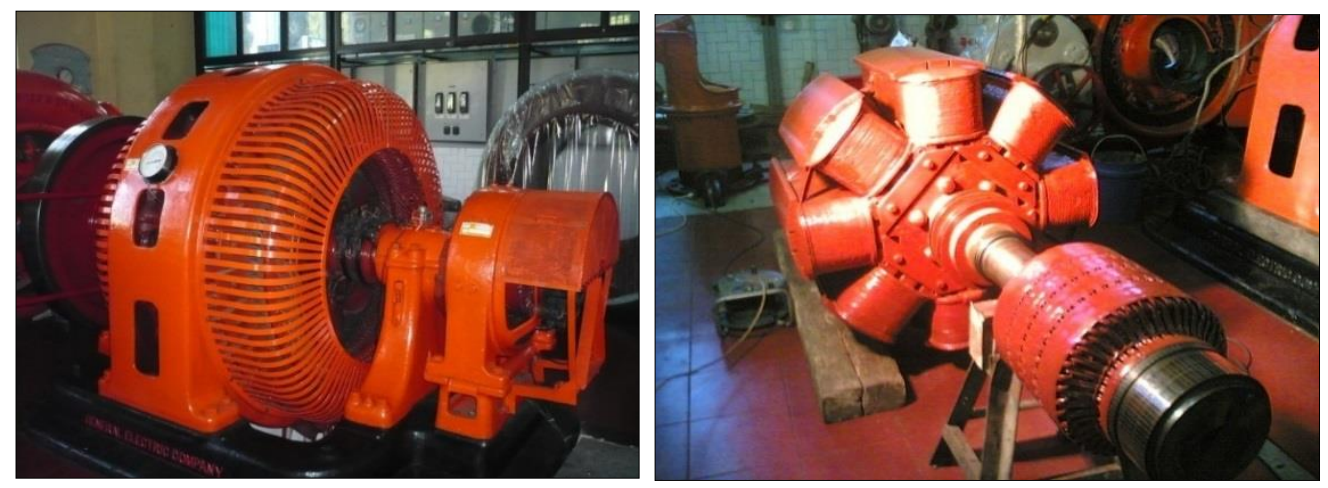

Gambar 1.19 Generator

- Merk

- Buatan

- Tahun pembuatan

- Type

- Tegangan

- Arus
: Escher Wyss

: Swiss

: 1923

: Horizontal

: 6000V

: 175 Ampere

\section{Jenis - Jenis PLTA ( Pembangkit Listrik Tenaga Air )}

Menurut aliran airnya PLTA dapat dibagi menjadi tiga jenis yaitu :

- PLTA aliran langsung (run-off-river), yaitu PLTA yang dalam membangkitkan tenaga listriknya dengan memanfaatkan aliran sungai secara langsung atau alamiah.

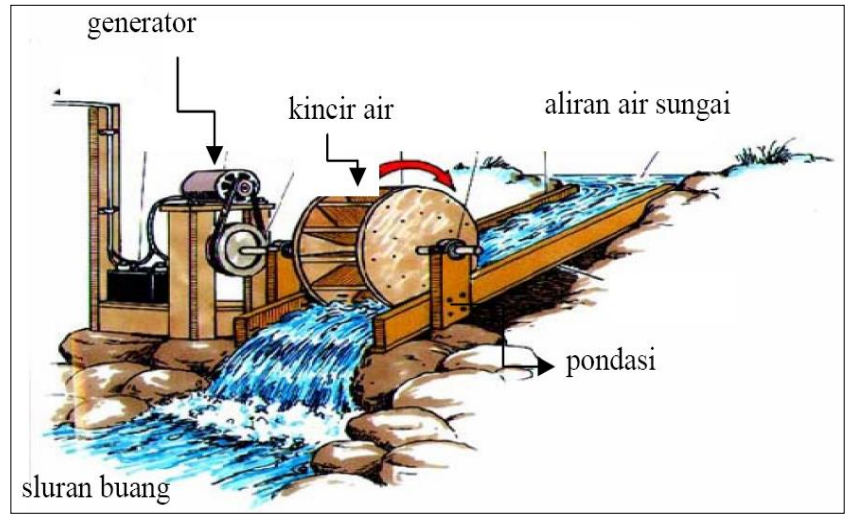

Gambar 1. 20 PLTA Aliran Langsung 
- PLTA kolam pengatur (regular pond), yaitu PLTA yang dalam membangkitkan tenaga listriknya dengan menggunakan kolam pengatur yang berfungsi untuk mengatur debit aliran sungai. Kolam ini dibangun melintang antara sungai yang melintasinya.

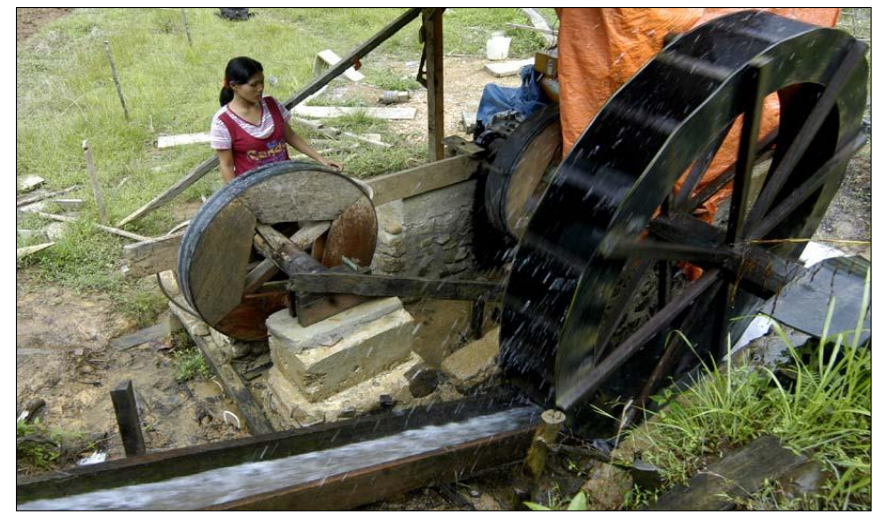

Gambar 1.21 PLTA Kolam Pengatur

- PLTA waduk (reservoir) yaitu PLTA yang dalam membangkitkan tenaga listriknya dengan menggunakan bendungan sebagai tempat penyimpanan airnya.

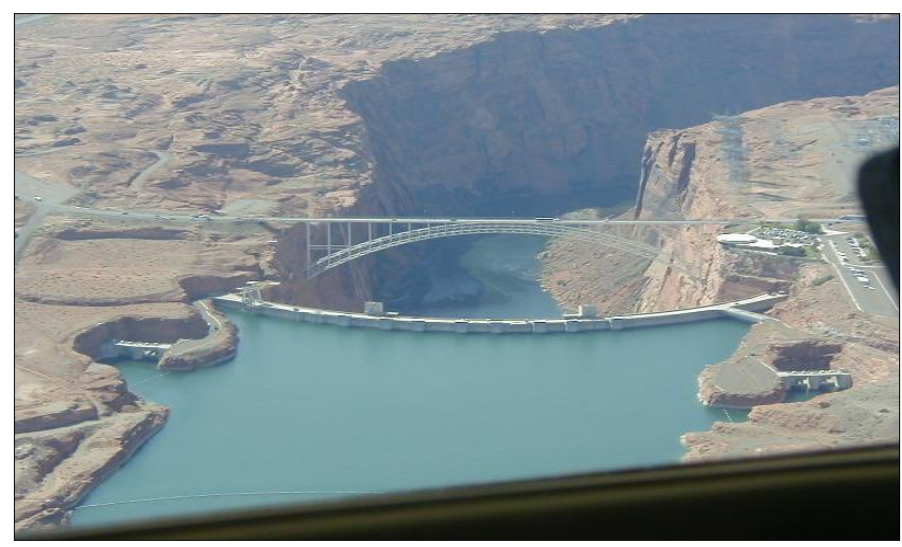

Gambar 1.22 PLTA Waduk 


\subsection{Pengertian Aliran Laminar dan Turbulen}

Aliran dapat diklasifikasikan dalam banyak jenis seperti : aliran turbulen, aliran laminar, aliran nyata, aliran ideal, aliran mampu balik, aliran tak mampu balik, aliran seragam, aliran tak seragam, aliran rotasional, dan aliran tak rotasional.

Aliran fluida yang mengalir di dalam pipa terdapat dua jenis aliran yaitu :

1. Aliran laminar

2. Aliran turbulen

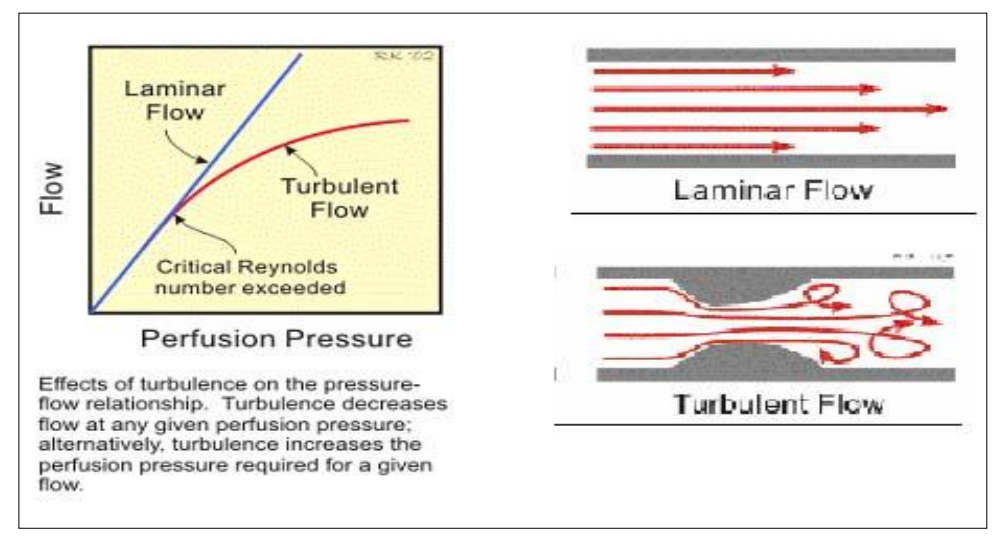

Gambar 1.23 Jenis Aliran

\section{Aliran Laminer}

Dalam aliran laminer partikel - partikel, fluidanya bergerak di sepanjang lintasan - lintasan lurus, sejajar dalam lapisan - lapisan. Besarnya kecepatan - kecepatan dari lapisan yang berdekatan tidaklah sama. Aliran laminer diatur oleh hukum yang menghubungkan tegangan geser ke laju perubahan bentuk sudut, yaitu hasilkali kekentalan fluida dan gradient kecepatan.

Kekentalan fluida tersebut dominan dan karenanya mencegah setiap kecenderungan menuju kondisi - kondisi turbulen.

Kecepatan kritis yang punya arti penting praktis bagi insinyur adalah kecepatan di bawah, dimana semua turbulensi diredam oleh kekentalan fluida. Telah 
ditemukan bahwa batas atas aliran laminar yang mempunyai arti penting dinyatakan oleh suatu bilangan Reynolds sebesar kira - kira 2000.

\section{Aliran Turbulen}

Aliran turbulen adalah aliran yang tidak terorganisir pada suatu lapisan di dalam fluida dimana partikel bergerak secara acak tidak menentu ke segala arah (satu partikel sulit untuk diikuti gerakannya).

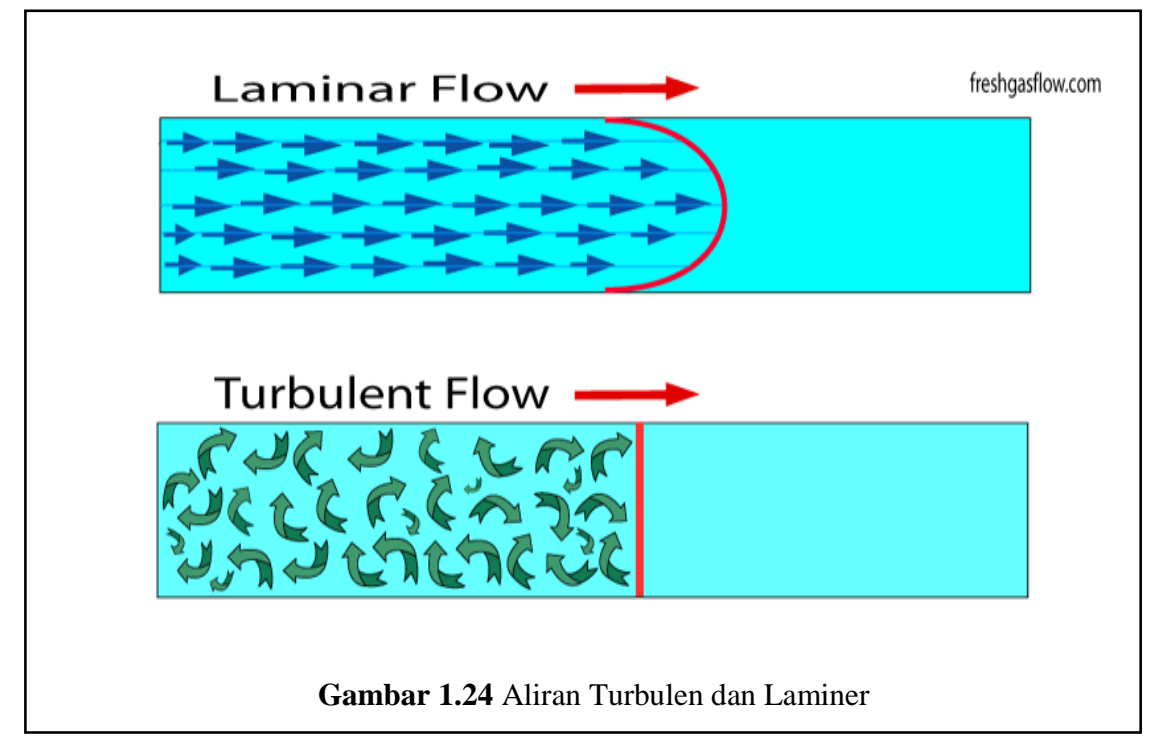

\section{Bilangan Reynold}

Bilangan Reynold adalah bilangan yang tak bedimensi, menyatakan perbandingan gaya - gaya inersia terhadap gaya - gaya kental.

$$
\begin{aligned}
& \mathrm{V}=\text { Kecepatan rata }- \text { rata }(\mathrm{m} / \mathrm{s}) \\
& \mathrm{D}=\text { Diameter Pipa }(\mathrm{m}) \\
& \rho=\text { massa jenis fluida }\left(\mathrm{kg} / \mathrm{m}^{3}\right) \\
& \mu=\text { Viskositas Dinamis }\left(\mathrm{N} . \mathrm{s} / \mathrm{m}^{2}\right)
\end{aligned}
$$




$$
\mathrm{Re}=\frac{p u d}{\mu}
$$

Konversi satuan Bilangan Reynolds

$$
\begin{aligned}
& \rho=k g / m^{3}, \quad u=m / s, \quad d=m \\
& \mu=N_{s} / m^{2}=k g / m s \\
& \operatorname{Re}=\frac{\rho u d}{\mu}=\frac{k g}{m^{3}} \frac{m}{s} \frac{m}{1} \frac{m}{k g}=1
\end{aligned}
$$

\section{$\underline{\text { Aliran laminar }}$}

- $\operatorname{Re}<2000$

- Kecepatan Rendah

- Fluida partikel bergerak dalam garis lurus

- Perhitungan hanya menggunakan analisis matematika sederhana

- Jarang diterapkan pada sistem air

\section{$\underline{\text { Aliran turbulen }}$}

- $\operatorname{Re}>4000$

- Kecepatan Tinggi

- Bentuk aliran benar-benar tidak teratur

- Tidak bisa dilihat dengan mata telanjang

- Perubahan / fluktuasi sangat sulit untuk dideteksi.

- Analisis matematis yang sangat sulit

- Diterapkan pada system air. 


\subsection{Komponen - Komponen Yang Penting Pada Sistem Pemipaan}

\subsubsection{Katup (Valve)}

Salah satu komponen yang penting pada sistem perpipaan adalah katup. Disini hanya akan dibicarakan mengenai katup yang umum dipergunakan pada suatu kilang.

Beberapa jenis katup :

1. Katup Pintu (Gate Valve), digunakan untuk pengaturan aliran, baik dengan membuka atau menutup katup sesuai dengan kebutuhan.

2. Katup Bola (Globe Valve), digunakan untuk membuka seluruhnya atau menutup sama sekali alirannya.

3. Katup Chek ( Check Valve), digunakan untuk mencegah aliran balik atau dengan kata lain, digunakan hanya untuk aliran satu arah.

Katup pintu dan katup bola dioperasikan dengan memutar sebuah roda.

Ada tiga variasi pemutaran katup pintu yang bekerja cepat dan katup-katup tersebut mempunyai kegunaan khusus yaitu :

1. Katup kupu-kupu (Butterfly Valve), dengan katup tipis, ringan dipakai untuk air.

2. Ball Valve, dipakai untuk gas-gas.

3. Plug Valve, dipakai untuk minyak dan pelumas kental.

Dari macam-macam katup tersebut diatas, masing-masing mempunyai beberapa variasi dalam bentuk dan cara kerjanya. 


\subsubsection{Bahan atau Material Katup}

Suatu hal yang penting dalam pemakaian katup adalah memilih material katup yang sesuai dengan perencanaan.

Bahan yang dipakai untuk pembuatan katup adalah :

a. Kuningan (brass), katup dengan bahan ini digunakan untuk temperatur di bawah $450{ }^{\circ} \mathrm{F}$, bila temperaturnya lebih besar dari $550^{\circ} \mathrm{F}$ maka digunakan material perunggu (bronze) yang biasanya mempunyai diameter minimum 3 inchi, dan tekanan dapat lebih besar dari 330 psi.

b. Besi (iron), macam-macamnya adalah mulai dari cast iron yang biasa digunakan untuk katup kecil sampai kepada high strength metal alloy cast yang digunakan untuk katup besar cast iron tidak boleh digunakan untuk temperatur lebih besar dari $450^{\circ} \mathrm{F}$.

c. Baja (Steel), material ini dipakai untuk katup yang memerlukan tekanan dan temperatur tinggi.

d. Stainless steel, material ini dipakai untuk katup yang memerlukan temperatur rendah atau aliran korosif.

Contoh gambar untuk jenis - jenis katup : 

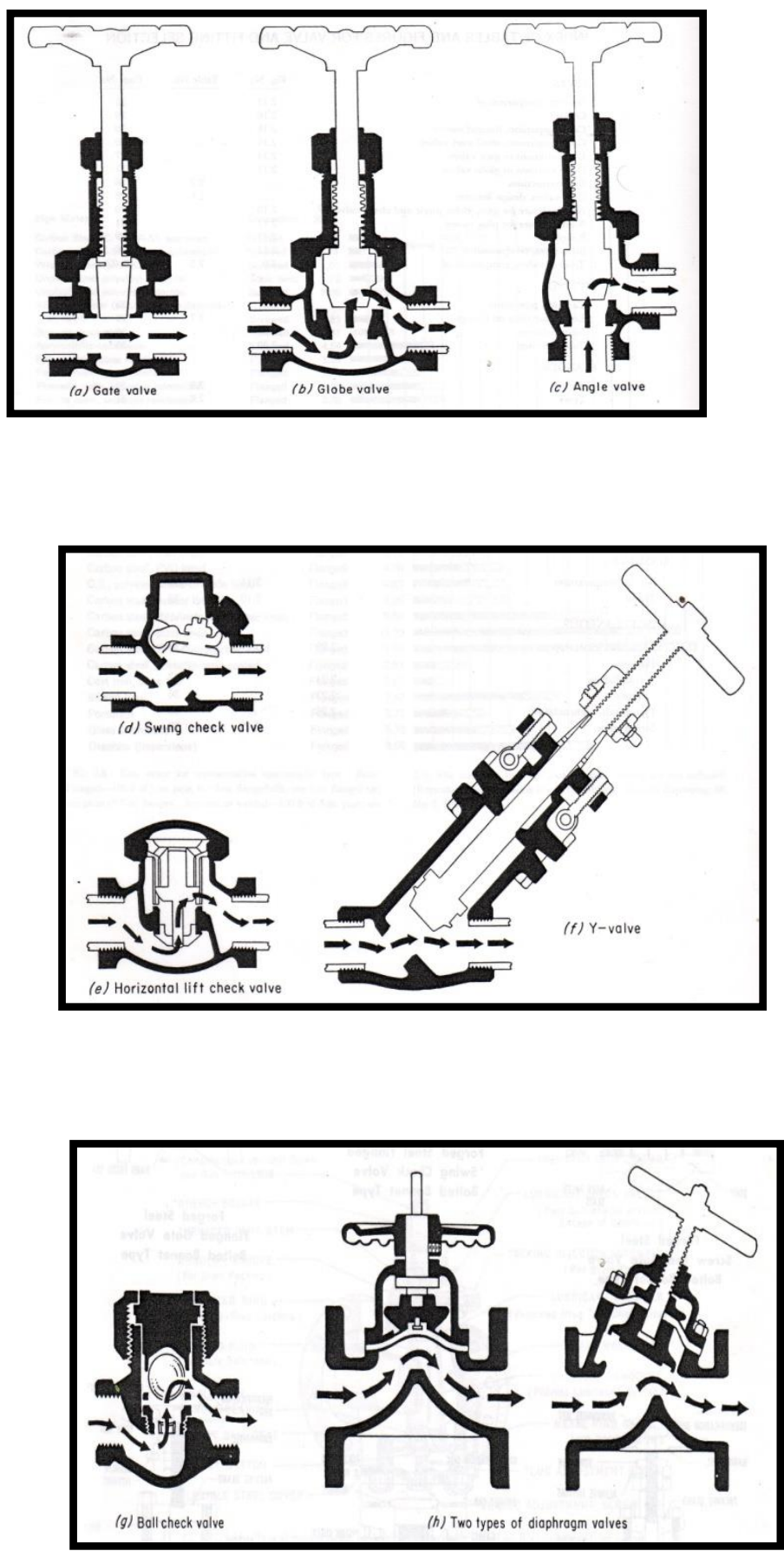

Gambar 1.25 Jenis-Jenis Katup 


\subsubsection{Saringan (Strainer)}

Saringan (strainer) adalah sebagai alat penyaring kotoran baik yang berupa padat, cair atau gas. Alat penyaringan ini digunakan pada jalur pipa guna menyaring kotoran pada aliran sehingga aliran yang akan diproses atau hasil proses lebih baik mutunya.

Adapun tipe-tipe alat penyaring ini dapat dibagi menjadi :

a.Tipe $\mathrm{T}$, tipe ini digunakan secara umum untuk memperluas ruang dan mereduksi tekanan pada jalur pipa

b.Tipe Y, digunakan untuk menyaring kotoran secara langsung dan menyaringnya ke bawah.

c. Tipe sementara, digunakan pada saat star up atau pengetesan

d.Tipe Bucket, digunakan untuk menyaring aliran yang lurus, selain itu alat penyaringnya tergantung dari karakteristik dari jenis cairan.

\subsubsection{Sambungan (Elbow)}

Adalah pipa yang berguna untuk menyambungkan pada pipa yang lainnya, biasanya jenis elbow yang digunakan antara lain : elbow $450^{\circ}$, elbow $60^{\circ}$, elbow $90^{0}$ dan pitting. 


\subsubsection{Pipa}

Adalah pipa yang berguna untuk mengalirkan aliran fluida disebut juga pipa hisap harus diatur sedemikian rupa guna mencegah penurunan tekanan yang dapat pula menimbulkan kavitasi.

Jenis-jenis material yang umum digunakan :

a. Pipa vetrified clay (pipa yang terbuat dari tanah liat)

Banyak yang digunakan untuk aliran pembuangan dengan sitem pengangkutan berdasarkan gaya berat, misalnya ; kotoran-kotoran manusia dan pembuangan kotoran lainnya dengan aliran bertekanan dan temperatur rendah.

b.Cast Iron soil pipe (besi tuang untuk dalam tanah)

Pipa ini kemampuan kekuatannya diatas pipa tanah liat dan boleh dipasang dibawah bangunan serta concrete yang tebal. Pipa ini dapat pula mengalirkan cairan yang cukup panas.

c. Carbon steel piping (pipa baja karbon)

Pipa ini banyak digunakan karena mudah dipasang, tapi untuk melindungi karat dari luar biasanya dilapis dengan bahan anti karat. Bahan anti karat ini lebih baik menggunakan pelapis plastik seperti scotch kote atau plicoflex, karena lebih tahan dari pada pelapis dari aspal atau residu.

d. Cast Iron water pipe (besi tuang pipa air)

Adalah digunakan untuk pembuangan air dengan tekanan tertentu. 


\section{e. Concrete pipe (pipa beton)}

Pipa ini digunakan untuk pembuangan kotoran air dengan ukuran 24“ atau lebih.

f. Concrete lined steel pipe (pipa baja dilapis semen)

Pipa ini digunakan untuk pembuangan kotoran cairan yang korosif serta mempunyai tekanan diatas kemampuan pipa besi tuang.

\section{g. Duriron Pipe}

Pipa ini digunakan untuk pembuangan cairan dengan tingkat korosi yang tinggi. Pipa ini sangat getas, sehingga harus hati-hati dalam pengangkutan dan pemasangan.

\subsection{Transmisi Listrik Jarak Jauh}

Pusat pembangkit listrik biasanya terletak jauh dari pemukiman atau pelanggan. Sehingga listrik yang dihasilkan pusat pembangkit listrik perlu ditransmisikan dengan jarak yang cukup jauh. Transmisi energi listrik jarak jauh dilakukan dengan menggunakan tegangan tinggi, dengan alasan sebagai berikut

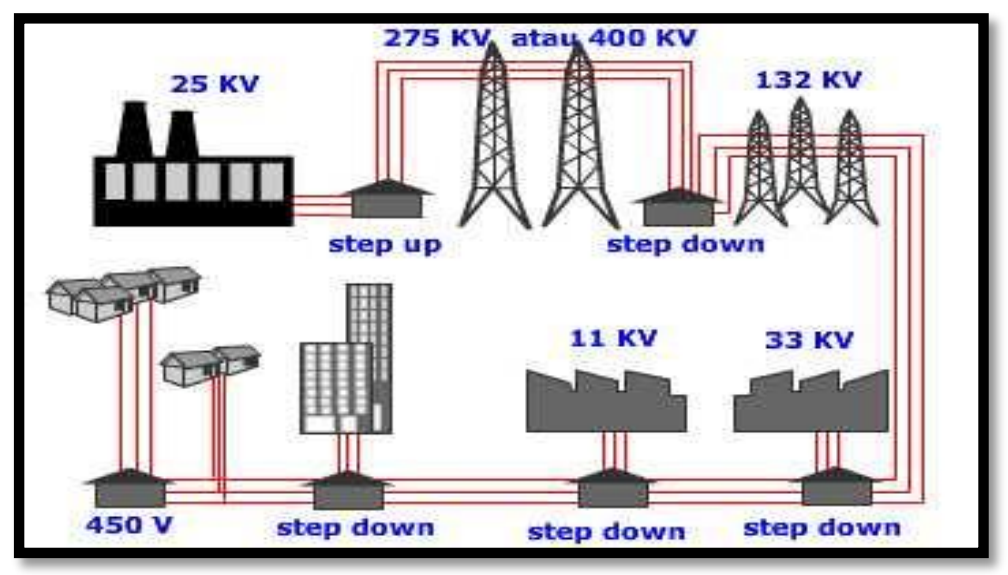

Gambar 1.26 Transmisi energi listrik jarak jauh 
1. Bila tegangan dibuat tinggi maka arus listriknya menjadi kecil.

2. Dengan arus listrik yang kecil maka energi yang hilang pada kawat transmisi (energi disipasi) juga kecil.

3. Juga dengan arus kecil cukup digunakan kawat berpenampang relatif lebih kecil, sehingga lebih ekonomis.

Energi listrik atau daya listrik yang hilang pada kawat transmisi jarak jauh dapat dihitung dengan persamaan energi dan daya listrik sebagai berikut:

$$
w=I^{2} x R x t \text { dan } P=I^{2} x R
$$

$\mathrm{W}=$ energi listrik (joule)

$\mathrm{I}=$ kuat arus listrik (ampere)

$\mathrm{R}=$ hambatan $(\mathrm{ohm})$

$\mathrm{t}=$ waktu

$\mathrm{P}=$ daya listrik (watt)

Transmisi energi listrik jarak jauh menggunakan tegangan tinggi akan mengurangi kerugian kehilangan energi listrik selama transmisi oleh disipasi.

Contohnya daya listrik $2 \mathrm{MW}$ ditransmisikan sampai jarak tertentu melalui kabel berhambatan 0,01 ohm. Hitung daya listrik yang hilang oleh transmisi tersebut, jika:

1. menggunakan tegangan 200 Volt,

2. menggunakan tegangan 400 kiloVolt?

Penyelesaian :

Diketahui :

$$
\begin{aligned}
& \mathrm{P}=2 \mathrm{MW}=2 \cdot 10^{6} \text { watt } \\
& \mathrm{R}=0,01 \mathrm{ohm}
\end{aligned}
$$


Ditanyakan: a. Philang pada tegangan 200 Volt $=\ldots \ldots \ldots . .$. ?

b. $P_{\text {hilang }}$ pada tegangan $\mathrm{V}=4.10^{5}$ volt $=$ ?

a.

$$
\begin{aligned}
& I=\frac{P}{V} \\
& I=\frac{2.10^{6}}{200} \\
& I=10^{4} \mathrm{~A} \\
& P=I^{2} \cdot R \\
& P=10000^{2} \cdot 0,01 \\
& P=10^{6} \text { Watt }
\end{aligned}
$$

$$
\text { b. } \begin{aligned}
I & =\frac{P}{V} \\
I & =\frac{2 \cdot 10^{6}}{4 \cdot 10^{5}} \\
I & =5 \mathrm{~A} \\
P & =I^{2} \cdot R \\
P & =5^{2} x 0,02 \\
P & =0,25 \text { Watt }
\end{aligned}
$$

- Jadi, energi yang hilang di perjalanan setiap detiknya $10^{6}$ watt. Nilai ini sangat besar karena setengah dayanya akan hilang.

- Jadi, energi yang hilang di perjalanan setiap detiknya hanya 0,25 watt. 